\title{
FACTORS AFFECTING THE SUCCESS THERAPY OF ANTIRETROVIRAL IN PEOPLE WITH HIV/AIDS IN PROF. DR. W.Z. JOHANNES HOSPITAL, KUPANG, EAST NUSA TENGGARA
}

\author{
Thomas Laga Boro, Rafael Paun, Marthen R. Pellokila, \\ Kori Limbong
}

\author{
Masters Program in Public Health, Universitas Nusa Cendana, \\ Kupang, East Nusa Tenggara Timur
}

\begin{abstract}
Background: HIV/AIDS is an important public health problem in the world including Indonesia. People living with HIV/AIDS (PLWHA) who are not on antiretroviral therapy for more than 3 months will have an impact on increased opportunistic infections and the risk of death. This study aimed to analyze the factors that influence the success of antiretroviral therapy in people living with HIV in Prof. Dr. W. Z. Johannes Hospital, Kupang.

Subjects and Method: This was an analytic observational study with a casecontrol design. The study was conducted at Prof. Dr. WZ Johannes Hospital, Kupang, East Nusa Tenggara, from October to November 2017. The sample was 66 people living with HIV who underwent antiretroviral therapy from 2006 to 2016. Samples were selected by simple random sampling. The dependent variable was the success of antiretroviral therapy. The independent variables were age, intention, self-efficacy, action, mode of transportation, cost, and duration of therapy. Antiretroviral therapy survival data was obtained from medical records. Other variable data were collected by questionnaire. Data were analyzed by simple logistic regression (bivariate analysis).

Results: The success of antiretroviral therapy increased with strong intentions $(\mathrm{OR}=4.67 ; \mathrm{p}=0.004)$, self efficacy $\mathrm{OR}=7.87 ; \mathrm{p}<0.001)$, duration of therapy $\geq 6$ months $(\mathrm{OR}=25.00 ; \mathrm{p}=0.003)$, action $(\mathrm{OR}=45.45 ; \mathrm{p}<0.001)$, sea transport mode $(\mathrm{OR}=3.66 ; \mathrm{p}=0.046)$, and cost $(\mathrm{OR}=19.23 ; \mathrm{p}<0.001)$. The success of antiretroviral therapy decreased with age $\geq 56$ years $(\mathrm{OR}=0.25 ; \mathrm{p}=0.215)$.

Conclusion: Factors influencing the success of antiretroviral therapy are an intention, self-efficacy, duration of therapy, action, mode of transportation, cost, and age.
\end{abstract}

Keywords: HIV/AIDS, antiretroviral therapy, follow-up, duration of therapy

\section{Correspondence:}

Thomas Laga Boro. Masters Program in Public Health, Universitas Nusa Cendana, Kupang, East Nusa Tenggara. Email: boro_t@yahoo.co.id.

Mobile: 081339447395 . 